\title{
A paternal influence on the embryonic capacity for implantation observed in a surrogate motherhood program
}

\begin{abstract}
Objective: We evaluated the influence of semen quality on the outcome of a surrogate motherhood program (SMP).

Design: Thirty two couples (group A) with normal semen parameters (i.e., sperm concentration, $\%$ motile sperms, and \% morphologically normal sperms) of semen analysis participated in our SMP. Another group of 28 couples (group B) with an abnormal value in at least one semen parameter was also included in this SMP-study.

Materials and methods: All female partners underwent ovarian stimulation and semen samples were collected from the male partners. These women asked to participate in our SMP because of a history of hysterectomy or the presence of malignant hypertension, sickle cell anemia, chronic renal failure, or liver insufficiency (among others). ICSI techniques were performed in all mature oocytes of each couple of groups A and B. One surrogate woman underwent transfer of two embryos generated from each couple of groups A and B. Thus 32 surrogate women received embryos from the group A and 28 surrogate women received embryos from the group B. In addition, 31 couples (group C) with normal semen parameters participated in our SMP asking additionally for donor oocytes. Another group of 26couples (group D) with an abnormal value in at least one parameter of semen analysis was also included in this SMP-study asking additionally for donor oocytes.
\end{abstract}

Results: The $\%$ fertilized oocytes (at 18 hours post-ICSI), the $\%$ cleaved oocytes (at 36 hours post-ICSI), and the \% 8-12-cell stage embryos (at 72hours post-ICSI) were significantly lower $(\mathrm{P}<0.05$; Chi square test $)$ in group $\mathrm{B}$ than in group $\mathrm{A}$ and in group $\mathrm{D}$ than in group $\mathrm{C}$. The proportion of [the pregnant surrogate women] to [the total number of the surrogate women who underwent embryo transfer] was significantly lower in group $\mathrm{B}(8 / 28)$ than in group $\mathrm{A}(14 / 32)(\mathrm{P}<0.05$; Chi square test $)$ and in group D $(8 / 26)$ than in group C (14/31).

Conclusion: Couples requesting to participate in an SMP with at least one abnormal semen parameter have worse prognosis to achieve pregnancy suggesting that paternal factors affect detrimentally the outcome of SMP. Paternal factors affecting the last events of the fertilization process (such as oocyte activating factor, reproducing element of the centrosome, among others) and early embryonic development or embryonic capacity for implantation (i.e. paternal DNA fragmentation, sperm nuclear proteins, paternal chromosomal aberrations, among others) may be the connective links between decreased semen quality and less optimal outcome in an SMP.
Volume 5 Issue 4 - 2017

\author{
I Giakoumakis,' D Daphnis,' E \\ Vlachopoulou, ${ }^{2} \mathrm{~K}$ Zotos, ${ }^{2} \mathrm{G}$ Daligkaros, ${ }^{2} \mathrm{~N}$ \\ Sofikitis ${ }^{2}$ \\ 'Mediterranean Fertility Center \& Genetic Services, Greece \\ ${ }^{2}$ Department of Urology, loannina University School of \\ Medicine, Greece
}

\section{Correspondence: loannis Giakoumakis, OB-GYN, Clinical Director of Mediterranean Fertility Institute (Surrogacy, Egg Donation, In Vitro Fertilization Program), Alexandra General Hospital in Athens, 24 Zimvrakakidon St., Chania, Greece,} Email igiakoumakis@ivfgreece.com

Received: July 10, 2017 | Published: July 10, 2017

\section{Introduction}

Previous studies from Janny and Menezo have provided evidence for a strong paternal effect on human preimplantation embryo development and blastocyst formation. ${ }^{1}$ The studies by Janny and Menezo have been confirmed by other groups:

"Post-fertilization effects of chronic renal failure in male rats".

In fact fertilization rate, cleavage rate, blastocyst development rate, and live birth rate are significantly smaller after IVF methods using spermatozoa from rats with chronic renal failure compared with healthy rats. The initial study by Janny and Menezo has been further confirmed by an additional report which shows that effects of primary testicular damage on sperm DNA may cause oxidative status and embryonic and foetal development if there is fertilization. ${ }^{3}$ In fact fertilization rate, cleavage rate, blastocyst development rate, and live birth rate are significantly smaller after IVF methods using spermatozoa from rats with varicoceles compared with healthy rats. An additional confirmation was published in rabbits with varicocele where it revealed a detrimental effect of left varicocele in the reproductive capacity of the early haploid male gamete. ${ }^{4}$ In fact ooplasmic injections (ICSI) of round spermatid nuclei from rabbits with primary testicular damage are significantly smaller compared with healthy rabbits (Table 1). 
Table I Functions of the centrosome

\begin{tabular}{|c|c|c|}
\hline Function & $\begin{array}{l}\text { Responsible } \\
\text { element }\end{array}$ & Inheritance mode \\
\hline \multicolumn{3}{|l|}{ Intrinsic } \\
\hline Reproducing element & Unknown & Paternal \\
\hline Microtubule organizer & $\begin{array}{l}\text { Unknown } \\
\gamma \text {-tubulin binding } \\
\text { protein }\end{array}$ & Paternal \\
\hline $\begin{array}{l}\text { Microtubule nucleation } \\
\text { peripheral }\end{array}$ & $\begin{array}{l}\text { Tubulin, probably } \\
\text { in the } 25 \mathrm{~S} " \gamma \\
\text {-some" }\end{array}$ & $\begin{array}{l}\text { Largely maternal, } \\
\text { Perhaps secondarily } \\
\text { derived from function } \\
\text { number }\end{array}$ \\
\hline \multicolumn{3}{|l|}{ Peripheral } \\
\hline $\begin{array}{l}\text { Nuclear association and } \\
\text { nuclear(karyogamy) }\end{array}$ & $\begin{array}{l}\text { Gene products } \\
\text { of various } \\
\text { mutants, including } \\
\text { mutations in } \\
\text { motor proteins }\end{array}$ & 2 \\
\hline $\begin{array}{l}\text { Configurational } \\
\text { destruction }\end{array}$ & $\begin{array}{l}\text { Affected and } \\
\text { effected by } \\
\text { MTs and MFs, } \\
\text { including both } \\
\text { cell cycial shape } \\
\text { changes and } \\
\text { antiperpendicular } \\
\text { separation }\end{array}$ & 2,3 \\
\hline $\begin{array}{l}\text { Cendtrosome } \\
\text { destruction }\end{array}$ & $\begin{array}{l}\text { Absence of } \\
\text { duplication of } \\
\text { reproducing } \\
\text { elements results } \\
\text { in centrosome } \\
\text { destruction }\end{array}$ & Absence of 1 \\
\hline $\begin{array}{l}\text { The cell's pacemaker } \\
\text { orchestrator of the cell } \\
\text { cycle's regulation }\end{array}$ & $\begin{array}{l}\text { Arrangement of } \\
\text { kinases, cyclins, } \\
\text { phosphatase }\end{array}$ & 2 \\
\hline $\begin{array}{l}\text { Centriole assembly and } \\
\text { axoneme excision }\end{array}$ & $\begin{array}{l}\text { Involoves centrin } \\
\text { and microtubule } \\
\text { assembly, and } \\
\text { excision is } \\
\text { included by the } \\
\text { binding of calcium } \\
\text { ions to centrin }\end{array}$ & 2 \\
\hline Cell body organizer & $\begin{array}{l}\text { Perhaps derived } \\
\text { from microtubules }\end{array}$ & 2 \\
\hline
\end{tabular}

\section{Suggestion}

Our suggestion is that the mission of the male gamete is not only to fertilize the oocyte but the male gamete contributes with factors important for the early embryonic development and embryonic capacity for implantation.

\section{A surrogate motherhood program}

Considering that young healthy women serve as surrogate mothers it appears that a surrogate motherhood program offers a unique opportunity to appreciate the contribution of paternal factors to the early embryonic development and to the embryonic capacity for implantation.

\section{Objective}

Our objective was to evaluate the influence of semen quality on the outcome of a surrogate motherhood program (SMP). Past studies by Schatten et al have demonstrated that the human centrosome is paternally inherited.

Major Contributions of the Male Gamete to the Zygote,

i. DNA,

ii. Nuclear Protein Matrix,

iii. Centrosomic Components,

iv. Oocyte activating substance.

\section{Participants and methods}

This study involves 4 groups:

i. Group A ( $\mathrm{n}=32)$ : Couples with normal concentration, motility and morphological aspects.

ii. Group B ( $\mathrm{n}=28)$ : Couples with an abnormal value in at least one of the above parameters.

iii. Group C $(n=31)$ : Couples with normal normal concentration, motility and morphological aspects asking additionally for donor oocytes.

iv. Group $\mathrm{D}(\mathrm{n}=26)$ : Couples with an abnormal semen parameter asking additionally for donor oocytes.

\section{Embryo transfer}

(Table 2) Every surrogate woman underwent transfer up to two embryos generated from groups A, B, C, or D. Within each column, values not sharing the same superscript $\mathrm{a}$ or $\mathrm{b}$ are statistically significantly different $(\mathrm{P}<0.05)$ (Table 3$)$. There is a significant difference in all parameters when comparing Group A VS Group B and Group C VS Group D.

Table 2 Pregnancy in the surrogate motherhood program

\begin{tabular}{lll}
\hline Group & $\begin{array}{l}\text { Number of women } \\
\text { undergone ET }\end{array}$ & Pregnant women (\%) \\
\hline A & 32 & $14(43 \%)^{\mathrm{a}}$ \\
B & 28 & $8(28 \%)^{\mathrm{b}}$ \\
C & 31 & $14(45 \%)^{\mathrm{a}}$ \\
D & 26 & $8(30 \%)^{\mathrm{b}}$ \\
\hline
\end{tabular}

Table 3 Effect of sperm quality on embryonic dynamics

\begin{tabular}{llll}
\hline Group & Fertilisation rate & Cleavage rate & $\begin{array}{l}\text { 8-10 cell stage } \\
\text { embryos rate }\end{array}$ \\
\hline A & $132 / 221(59.7 \%)^{\mathrm{a}}$ & $87 / 132(65.9 \%)^{\mathrm{a}}$ & $64 / 87(73.5 \%)^{\mathrm{a}}$ \\
B & $98 / 223(43.9 \%)^{\mathrm{b}}$ & $49 / 98(50.0 \%)^{\mathrm{b}}$ & $29 / 49(59.1 \%)^{\mathrm{b}}$ \\
C & $117 / 186(62.9 \%)^{\mathrm{a}}$ & $79 / 117(67.5 \%)^{\mathrm{a}}$ & $68 / 79(86.0 \%)^{\mathrm{a}}$ \\
D & $75 / 156(48.0 \%)^{\mathrm{b}}$ & $39 / 75(52.0 \%)^{\mathrm{b}}$ & $28 / 39(71.7 \%)^{\mathrm{b}}$ \\
\hline
\end{tabular}




\section{Results}

i. Couples participating in an SMP and use the female partner's oocytes have significantly smaller live birth rate if there is an abnormal value in the normal concentration, motility and morphological aspects.

ii. Couples participating in an SMP and use donor oocytes have significantly smaller live birth rate if there is an abnormal value in the normal concentration, motility and morphological aspects.

\section{Conclusion}

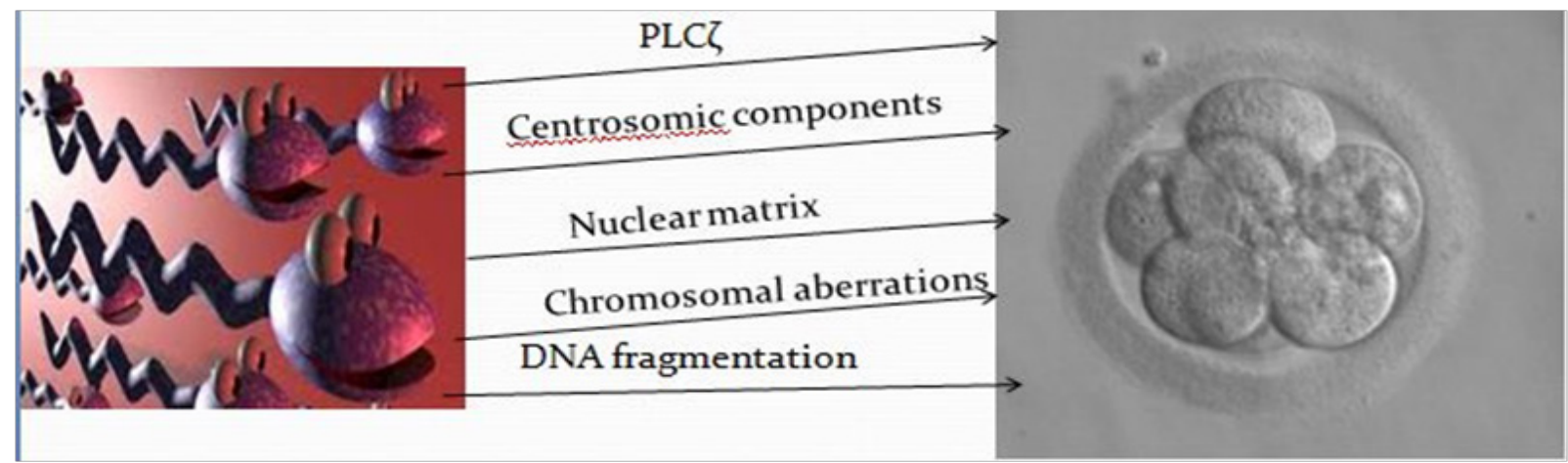

i. In conclusion increased defects in spermatozoa concerning number, motility and morphology affect detrimentally the above mentioned parameters.

ii. This will result in a lower probability for optimal embryonic development and capacity for implantation.

\section{Acknowledgements}

None.

\section{Conflict of interest}

The author declares no conflict of interest.

\section{References}

1. Janny L, Menezo YJ. Evidence for a strong paternal effect on human preimplantation embryo development and blastocyst formation. Mol Reprod Dev. 1994;38(1):36-42.

2. Dimitriadis F, Giannakis D, Giotitsas N, et al. Post-fertilization effects of chronic renal failure in male rats. Int $J$ Androl. 2009;32(6):675-686.

3. Dimitriadis F, Giannakis D, Pardalidis N, et al. Effects of primary testicular damage on sperm DNAoxidative status and embryonic and foetal development. Andrologia. 2009;41:282-296.

4. Sofikitis NV, Miyagawa I, Incze P, et al. Detrimental effect of left varicocele on the reproductive capacity of the early haploid male gamete. $J$ Urol. 1996;156(1):267-270. 